\title{
FICTITIOUS ADMINISTRATIVE ACTS: PROSPECTS OF REGULATION IN THE COUNTRIES OF CENTRAL ASIA
}

The Central Asian countries - Kazakhstan (twice: in 2000, 2015-2016), Kyrgyzstan (twice: in 2004, 2015), Tajikistan (in 2007), and Uzbekistan (twice: in 2007, 2015-2016) - are trying to implement laws on administrative procedure into their national legal systems. Laws on administrative procedure are a tool of western philosophy, an institute of European administrative law of the European understanding of open government and effective administrative regulation, approaches to which the countries of the region have begun to develop relatively recently. Instead of a formal pursuing the adoption of laws on administrative procedure, it is more important to find answers to the countries' readiness to accept laws on administrative procedure into their existing social, political and economic realities, including the peculiarities of the legal systems. The research notes a lack of two key concepts of the laws on administrative procedure - the concept of administrative procedures as such and the concept of administrative acts. It is analyzed the possibility of implementation of one of the variants of the administrative decision adopted as the result of a fictitious approval (Genehmigungsfiktion). Today, in Central Asia a truncated model of fictitious approval is in operation - the principle "silence gives consent" - within the sphere of licensing procedures of entrepreneurship: "if the public authority does not submit within the established deadlines a motivated refusal or authorization document, such a document is considered to be issued (i. e. the procedure is deemed to be completed)". The article provides its comparative legal analysis of the application of fictitious approval in the countries of Central Asia.

The author arrives at a number of conclusions:

- administrative "silence" can be used by the legislator as a fictitious administrative act (tacit consent);

- administrative "silence" is a form of an administrative act, but only on the basis of legislative clauses;

- objective limitations of the use of administrative "silence" are shown;

- different types of inactivity are classified for its effective objection, the position of the term in the system of such definitions as "administrative silence", "delay in the adoption of an administrative act".

Key words: administrative procedures, administrative act, administrative "silence", fictitious approval, Central Asia. 
Leonid Khvan, PhD in Law, Associate Professor

(Tashkent, Uzbekistan)

\section{Introduction}

Countries of the Central Asia - Kazakhstan (twice: in 2000 and 2015-20161), Kyrgyzstan (twice: in 2004, 2015²), Tajikistan (in 2007), and Uzbekistan (twice: in 20073, 2015-2016 ) were among the first in the post-Soviet space which attempted to assimilate statutory provisions on administrative procedures. Alot of people wonder why the laws didn't become valid after a long period, why they didn't lead to changes in law enforcement of administrative authorities, in government management of the economy, why it didn't affect the confidence in the public institutions. Why didn't the changes take place at the level of legal consciousness, why didn't standpoints and control options of civil society modify? Whether new attempts of the legislator will be

${ }^{1}$ Parliament of the Republic of Kazakhstan (2015). Draft Law of the Republic of Kazakhstan "On Administrative Procedures" dated December 30, 2015; updated on May 18, 2016. URL: http://www.adilet.gov.kz/ru/articles/zakon-respubliki-kazahstanob-administrativnyh-procedurah [Об административных процедурах : проект Закона Республики Казахстан от 30 декабря 2015 г.; обновлено 18 мая 2016 г. URL: http://www.adilet.gov. $\mathrm{kz} / \mathrm{ru}$ /articles/zakon-respubliki-kazahstan-ob-administrativnyhprocedurah].

${ }^{2}$ Parliament of the Kyrgyz Republic (2015). Law of the Kyrgyz Republic "On the Fundamentals of Administrative Activity and Administrative Procedures” dated July 31, 2015 № 210. ErkynToo, no. 78(2549) [Об основах административной деятельности и административных процедурах : Закон Кыргызской Республики от 31 июля 2015 г. № 210. Эркин-Тоо. 2015. № 78(2549)].

${ }^{3}$ Parliament of the Republic of Uzbekistan (2007). Law of the Republic of Uzbekistan "On Administrative Procedures" dated June 21, 2007 [Об административных процедурах : Закон Республики Узбекистан от 21 июня 2007 г.]. The Draft Law was developed with the assistance of GIZ \& JICA and included all fundamental provisions of the institute of administrative procedures. The Law was not approved by the Senate of the Oliy Majlis of the Republic of Uzbekistan.

${ }^{4}$ On January 23, 2015, the "Programm of Action of the Cabinet of Ministers of the Republic of Uzbekistan for the near and long term" was presented. It provided for measures to further liberalize the conditions for doing business, to completely eradicate the facts of unlawful interference of state bodies in private business, as well as to remove all obstacles and unreasonable restrictions.

See: Cabinet of Ministers of the Republic of Uzbekistan (2015). Programm of Action of the Cabinet of Ministers of the Republic of Uzbekistan for the near and long term. URL: http:/gov.uz./ru/ press/politics/29049 [Программа действий Кабинета министров Республики Узбекистан на ближайшую и долгосрочную перспективу. URL: http://gov.uz./ru/press/politics/29049]. 
successful or they suffer the fate of the previous versions of the laws on administrative procedures (hereinafter - "LAP"). There are no clear and system answers at the level of analytical research as well as in the official line of the legislator or executive authority, which are responsible for the current hard-hitting state of affairs in the relations "official citizen". On the one hand, there has been non-critical, formal pursuing of the adoption LAP and, on the other hand, one should look for a more appropriate answer in the analysis of available social, political and economic realities, including the special aspects of the national law enforcement. The legislator hasn't conducted social research in any of the abovementioned countries - doctrine is silent about it. There is no analysis of the institute of administrative procedures through the prism of four dimensions. This refers to the following aspects:

1) human rights and justice (human rights advocacy and LAP role);

2) the concept "good governance" (the assurance of proper administration, change of the composition of government machinery and LAP potential);

1) economic freedom (problems of activities of administrative regulators, LAP potential);

4) legal compatibility, priorities and adaptation (LAP position, system assimilation of framework LAP and its correlation with the legislation on public services, licensing procedures, civil service, e-governance etc.).

The analysis is important because LAP ideas are introduced in the government machinery for the first time and, at the same time, LAP is an instrument of the western world view, an institute of European administrative legislation and law, part of European understanding of open government and effective government regulation, approaches to which are actively elaborated by countries of the Commonwealth of Independent States (hereinafter - CIS). This is also an answer to the question on administrative procedures we need: concrete or declared ones. Now, there is no doubt that counties of the region have not bargained on the socio-legal concept of administrative procedures, including the fact that theory of administrative procedures develops ineffectively and slowly against the background of legislative changes. This is an obvious and one of the most serious challenges of the current preparation and upcoming implementation of LAP. Thus, there is scientific crudity of its two key provisions in evidence - the principles of administrative procedures and administrative act. Moreover, the modern concept of an administrative act, which has formed in the west doctrine of administrative law, significantly differs from the concept of individual legal act, which we have used both in the Soviet era of administrative law and the epoch of the contemporary history of CIS countries. The difference is based on the principles of interrelation of the government machinery and a citizen as a weaker party of legal relations. For a long time, the governments of CIS countries have been declaring the transition from an old system of public administration in which a citizen is a petitioner waiting for a decision of the administration to advanced democratic one where the building of new decent and fair relations "administration citizen" is fully and generally formulated as good governance \& best regulation \& better decision. However, sometimes it is left out of account the fact that LAP belongs to the legislative decisions requiring a special approach, including elaborated preparatory period and performance of a legal experiment. German researchers believe that 
the effectiveness of new laws on general administrative law is in the way how they will be is institutionally provided. This requires a primary in-depth analysis of that problems and context, legal culture and vital activities in which new LAP standards and sequent legal traditions are going to be introduced. Under that sort of system approach, there is a potential for the changes which, for example, in the context of conditions of Central Asia, will gradually propel "the relations of a citizen and the state to the next level". In 2013, the developed jurisdictions approved once again that citizen's right to good governance is a fundamental right ${ }^{5}$ and stated a direct interrelation between the fundamental human rights and administrative procedures. In essence, the LAP concept is integral to good governance where public power shows respect to a citizen and is ready to be accountable and open for non-governmental monitoring.

This article analyses one of the variants of an administrative act adopted as a result of a fictitious approval (Genehmigungsfiktion) ${ }^{6}$. Administrative "silence" is an obligatory part of the legal infrastructure of the government machinery created by LAP. SIGMA experts often emphasize: when an individual enters into legal relations with public administration, he faces many challenges as well as complexity, continuity and legal uncertainty of administrative procedures. This needs introducing some principles in terms of simplification of administrative procedures, inter alia, through a tacit consent - authorization by a competent agency after the termination of term designated for the adoption of an administrative $\mathrm{act}^{7}$. Italian professor Vera Parisio, the prominent researcher of the principle of administrative "silence", precisely notes that the objective of tacit consent is to avoid human suffering due to the ineffectiveness of public administration ${ }^{8}$. From this standpoint, the legislator and doctrine of administrative law of CIS countries have to give a relevant scientific assessment and elaborate an effective model for a practical application of administrative "silence", which objectively has not been a subject matter of analysis ${ }^{9}$ and, respectively, an element of law enforcement mechanism in the executive branch.

${ }^{5}$ European Parliament (2013). European Parliament resolution of 15 January 2013 with recommendations to the Commission on a Law of Administrative Procedure of the European Union (2012/2024(INL)). URL: https://www.europarl.europa.eu/sides/getDoc.do?reference=P7TA-2013-0004\&type $=$ TA\&language $=$ EN\&redirect $\#$ top.

${ }^{6}$ This is the name of a kind of administrative act in the LAP of Germany (section 42a Verwaltungsverfahrensgesetz (VwVfG)). See: German Parliament (1976). Administrative Procedure Act (VwVfG). URL: http://www.gesetze-im-internet.de/vwvfg/VwVfG.pdf [Verwaltungsverfahrensgesetz (VwVfG). URL: http://www.gesetze-im-internet.de/vwvfg/ VwVfG.pdf].

${ }^{7}$ Good Administration through a Better System of Administrative Procedures. SIGMA - the new Law on Administrative Procedures for Kosovo. October, 2012, pp. 21. URL: http://sigmaweb.org/ publications/Comments_LawAdminProceduresKosovo_JN_Oct2012_Eng\%20\%20.pdf.

${ }^{8}$ Parisio, V. (2013). The Italian Administrative Procedure Act and Public Authorities' Silence. Hamline Law Review, vol. 36, iss. 1, pp. 20. URL: https://digitalcommons.hamline.edu/cgi/ viewcontent.cgi? article $=1005 \&$ context $=$ hlr.

${ }^{9}$ Kilyaskhanov, I.Sh. (2005). The institute of justifiable defense in administrative law: conceptual frameworks and problems of legal content. Administrative law and process, no. 1, pp. 2-8 [Килясханов И.Ш. Институт необходимой защиты в административном праве: концептуальные основы и проблемы правового наполнения. Адміністративне право i проиес. 2005. № 1. C. 2-8]. 


\section{Legal assessment of administrative "silence" from the perspective of European principle "good governance"}

For the first time, the term of administrative "silence" emerged not in the EU legislation on administrative procedures but due to the EU Directive on the regulation of requests of EU citizens to obtain a permit for the public services provided in the EU countries (the Services Directive) ${ }^{10}$. However, in the very framework of working upon the rules of the Services Directive, it was concluded that the principle of tacit authorization by the competent authorities also should be included in the concept of the law on common administrative procedures. The principle contributes to the administrative simplification and the key point that it is the general principle of good governance.

The EU countries consider administrative "silence" as an instrument for the development of the administrative culture of the government machinery. In the well-known paper "The Right to Open Public Administrations in Europe: Emerging Legal Standards", West European analytics emphasized that many European legal orders in West and East Europe had and still have the problems of transparency and access to information, as the fundamental principle of public activities. Hence, the act of omission (silence) or delay in processing requests for access to public information often takes place ${ }^{11}$.

The above provision gained momentum and consolidation in $\operatorname{Rec}(2004) 20$ of the Committee of Ministers to member states on judicial review of administrative acts adopted on 15 December 2004. Paragraph 1a states that "administrative acts" mean the instances of refusal to act or omission to do so in cases where the administrative authority is under an obligation to implement a procedure following a request. Paragraph 15 of the Explanatory Memorandum to the Recommendation provides the following comment: the scope of administrative act also covers the situations of refusal or omission of administrative administration in cases where there is an obligation of administrative authority to act. The Recommendation considers that the concept of administrative act embraces the cases where the administration doesn't respond to an enquiry of an applicant or directly or indirectly refuses to adopt a relevant decision or action. The court shall be authorized to act in both situations. Then, paragraph 16 marks: "The interests of a citizen can't be violated by administration keeping silence under no circumstances. Upon expiry of the term specified by law, the silence shall make the court accessible. In such

${ }^{10}$ European Parliament (2006). Directive 2006/123/EC of the European Parliament and of the Council of 12 December 2006 on services in the internal market. URL: https://eur-lex. europa.eu/legal-content/EN/TXT/?uri=celex\%3A32006L0123.

European Parliament (2013). European Parliament resolution of 15 January 2013 with recommendations to the Commission on a Law of Administrative Procedure of the European Union (2012/2024(INL)). URL: https://www.europarl.europa.eu/sides/getDoc.do?reference=P7TA-2013-0004\&type $=$ TA\&language $=$ EN\&redirect\#top.

${ }^{11}$ OECD (2010). The Right to Open Public Administrations in Europe: Emerging Legal Standards. SIGMA Papers, no. 46, pp. 13. URL: https://www.oecd-ilibrary.org/ docserver $/ 5 \mathrm{~km} 4 \mathrm{~g} 0 \mathrm{zfqt} 27$-en.pdf? expires $=1588771648 \& \mathrm{id}=\mathrm{id} \&$ accname $=$ guest $\&$ checksum $=$ 902975228513E654C411013299853E82. 
cases, an administrative authority shall substantiate the reasons for application rejection upon request of the applicant or by court order" 12 .

In the European Parliament resolution of 15 January 2013 with recommendations to the Commission on a Law of Administrative Procedure, the Recommendation 4 (rules regulating administrative decisions) has an individual paragraph 4.2 which consolidates the following provision: "a notice on requests for individual decisions shall involve the time-limit for the adoption of the decision concerning the issue under consideration. The consequences of any failure to adopt the decision within that timelimit (administrative silence) shall be indicated"13.

Therefore, there is a sound international-legal substantiation of consideration of an administrative "silence" for a more system-based regulation of the institute of an administrative act at the level of national laws and thus, strengthening of positions of applicants in the case of appealing against all types of measures adopted by the administration.

In EU acquis administrative "silence means a fictitious administrative act or its kind, which is considered to be adopted within a time-limit specified by the law for a decision upon the request of an individual ${ }^{14}$. The general rule lies in the fact that administrative procedure shall be completed by the adoption of a particular administrative decision (favorable or unfavorable). Another option would mean not only the wrench of a legal role of public administration but also the violation of the most important principle of administrative procedures - the principle of regular expectations. Moreover, the LAP of many EU countries involves contiguous concepts, which should be taking into account and distinguish from the perspective of serving the interests of an applicant, e. g. delay in the adoption of an administrative act, omission of an administrative authority led to an absolute violation of proceedings for the administrative procedure (for example, administrative proceedings haven't been initiated, and any procedural action hasn't been performed) and, as a consequence, non-adoption of a formal administrative act.

In a legal logic of the institute of administrative procedures, the omission of the administrative authority is an independent kind of administrative action of public administration $^{15}$, e. g. refusal of the challenge of an official, redelivery of a petition on the issuance of the administrative act etc. (all types of such administrative actions can

\footnotetext{
${ }^{12}$ Council of Europe (2004). Recommendation Rec(2004)20 of the Committee of Ministers to member states on judicial review of administrative acts. URL: https://search.coe.int $/ \mathrm{cm} / \mathrm{Pages} /$ result_details.aspx?ObjectID $=09000016805 \mathrm{db} 3 \mathrm{f} 4$.

${ }^{13}$ European Parliament (2013). European Parliament resolution of 15 January 2013 with recommendations to the Commission on a Law of Administrative Procedure of the European Union (2012/2024(INL)). URL: https://www.europarl.europa.eu/sides/ getDoc.do?reference= P7-TA-2013-0004\&type $=$ TA\&language $=$ EN\&redirect\#top.

${ }^{14}$ Good Administration through a Better System of Administrative Procedures. SIGMA-the new Law on Administrative Procedures for Kosovo. October, 2012, pp. 22. URL: http://sigmaweb.org/ publications/Comments_LawAdminProceduresKosovo_JN_Oct2012_Eng\%20\%20.pdf.

${ }^{15}$ Aedmaa, A. et al. (2004). Administrative procedure guide. Tartu, pp. 537, 613, 626 [Руководство по административному производству / А. Аэдмаа, Э. Лопман, Н. Паррэст, И. Пилвинг, Э. Вэне. Тарту, 2004. 700 с.].
} 
be challenged regardless of the approval of the final administrative act). In the logic of the law concerning citizens' appeals of the Soviet era, omission of an official was also considered as an equivalent of an unlawful act of the official. Consequently, the omission of public administration is illegal, and this is the general principle in the assessment of its activity.

\section{A fictitious administrative act or administrative "silence" in the legislation of the countries of Central Asia}

Chapters of the LAP of Kazakhstan (incl. its new draft bill as of 2015), Kyrgyzstan (incl. its second version as of 2015), Tajikistan, Uzbekistan (draft bill as of 2016) devoted to an administrative act don't have any provisions on administrative "silence". However, the legislation of the region's countries on licensing procedures permits the application of the principle "silence gives consent", which is partly a prototype of administrative "silence".

\subsection{Kazakhstan}

In 2007, the principle "silence gives consent", stipulating automatic authorization of an applicant to carry out a licensable activity in case of licenser's non-response within the time-limit, was introduced in the Law of the Republic of Kazakhstan "On Licensing"16. Further, this principle was developed in many governmental concepts on business regulation and the elimination of administrative barriers ${ }^{17}$. In 2011, analyzing the state of affairs in the public administration, the government of Kazakhstan decided to consolidate the principle "silence gives consent" in its provisions through its extension to all licensing procedures for the reduction of time expenditures and business costs in legislation, simplification of licensing procedures. It was established that if a public authority fails to submit a reasoned refusal or an authorization document within the timelimits, such a document is considered to be issued (i. e. the procedure is interpreted to be completed). At the same time, an applicant shall not notify about the commencement of activities. In the context of improving the licensing system and control and supervisory activities of state bodies of Kazakhstan, it is determined the types of activities of medium danger level, which can be settled through regulators less tough than censoring (permits, accreditation, attestation, certification, etc.), and to which the principle "silence gives consent" will be applied ${ }^{18}$.

\footnotetext{
${ }^{16}$ Parliament of the Republic of Kazakhstan (2007). Law of the Republic of Kazakhstan "On Licensing" dated January 11, 2007. Bulletin of the Parliament of the Republic of Kazakhstan, no. 2, art. 10 [О лицензировании : Закон Республики Казахстан от 11 января 2007 г. Ведомости Парламента Республики Казахстан. 2007. № 2. Ст. 10].

${ }^{17}$ Government of the Republic of Kazakhstan (2008). Decree of the Government of the Republic of Kazakhstan "On the Concept for improving the licensing system in the Republic of Kazakhstan for 2009-2011” dated November 27, 2008 № 1100. URL: http://adilet.zan.kz/rus/docs/ Р080001100_ [О Концепции совершенствования разрешительной системы в Республике Казахстан на 2009-2011 годы : Постановление Правительства Республики Казахстан от 27 ноября 2008 г. № 1100. URL: http://adilet.zan.kz/rus/docs/P080001100_].

${ }^{18}$ Government of the Republic of Kazakhstan (2011). Resolution of the Government of the Republic of Kazakhstan "On the Draft of the Decree of the President of the Republic of Kazakhstan "On Modernization Concept of Public Administration System in the Republic of Kazakhstan" dated June 1, 2011 № 612. URL: http://adilet.zan.kz/rus/docs/P1100000612 [О проекте Указа Президента Республики Казахстан «О Концепции модернизации системы
} 
In 2012, for the implementation of the Decree of the President of the Republic of Kazakhstan dated January 30, 2012 № 261 “On Measures for the Exercise of the President's Address to the People of Kazakhstan dated January 27, 2012 "Socioeconomic modernization - a principal vector for the development of Kazakhstan", the government re-emphasizes that principle "silence gives consent" is designed to motivate government authorities to adhere to timescales established by the legislation to issue authorization documents and to promote business development outside administrative barriers ${ }^{19}$.

The Law of the Republic of Kazakhstan "On Permits and Notifications" dated May 16, 2014 doesn't identify the principle "silence gives consent" directly, however, the provisions of Art. 26 "Consequences of delay of the issuance of a permit" regulate the principle in details. The general rule states that carrying out of activity or actions (operations) by individuals and legal entities, for which the law has established the authorization-based or notification procedure, is impossible without a relevant permit or notification. If a licensing authority didn't issue a permit and/or appendix to the permit for an applicant within the time limits established by the law or didn't provide a reasonable refusal of issuance, the permit and/or appendix to the permit are considered to be issued from the date of expiry of time limits for their issuance and simultaneously included in the state electronic registry of permits and notifications by the licensing authority. On or prior to five working days after the expiry of time limit for the issuance of a permit and/or appendix to the permit, the authority shall provide an applicant with a relevant permit and/or appendix to the permit. If the authorization authority failures to issue the permit and/or appendix to the permit after five working days, the permit and/ or appendix to the permit shall be considered to be gained. Before obtaining a permit, a document acknowledging the acceptance of the relevant application for a permit by the authorized agency is the confirmation of activity's lawfulness.

The legislator stipulates the cases when the above provisions are not applicable, e. g. when issuing a license for conducting banking and other operations; for carrying out activities in the securities market; for the right to implement insurance (reinsurance) activity within a branch "blanket insurance"; in context of record registration

государственного управления в Республике Казахстан» : Постановление Правительства Республики Казахстан от 1 июня 2011 г. № 612. URL: http://adilet.zan.kz/rus/docs/ P1100000612].

${ }^{19}$ Government of the Republic of Kazakhstan (2012). Decision of the Government of the Republic of Kazakhstan "On the Concept of Further Reforming of Licensing System of the Republic of Kazakhstan for 2012-2015” dated July 11, 2012 № 929. URL: http://adilet.zan. kz/rus/docs/P1200000929\#z0 [О Концепции дальнейшего реформирования разрешительной системы Республики Казахстан на 2012-2015 годы : Постановление Правительства Республики Казахстан от 11 июля 2012 г. № 929. URL: http://adilet.zan.kz/rus/docs/ P1200000929\#z0].

Government of the Republic of Kazakhstan (2014). Decree of the Government of the Republic of Kazakhstan "On approval of the Concept of state regulation of entrepreneurial activity until 2020" dated April 18, 2014 № 380. URL: http://adilet.zan.kz/rus/docs/P1400000380 [Об утверждении Концепции государственного регулирования предпринимательской деятельности до 2020 года : Постановление Правительства Республики Казахстан от 18 апреля 2014 г. № 380. URL: http://adilet.zan.kz/rus/docs/P1400000380]. 
of micro-financial institutions; when issuing a permit for the possession of duty weapons and ammunition by legal entities or purchase of civilian weapons and ammunition by individuals, etc.

It is impossible to ignore the fact that in law, the principle "silence gives consent" also embraces the legal relations between administrative authorities which originate when a licensing authority requests for the reception of auxiliary permit (approval) by the relevant state body on the applicant's compliance or non-compliance with requirements when licensing or realizing authorization procedures. In particular, the law defines that the issuance of a permit is considered to be agreed if the state body hasn't responded within time limits.

Thus, the legislation of Kazakhstan actively uses an instrument of administrative "silence", but it hasn't regulated it under the LAP (versions as of 2000 and draft as of 2015) due to some reasons. Licensing procedures are an inherent part of the institute of administrative procedures, and it has a practical sense to specify an important provision on the completion of a procedure by adopting administrative act trough a fictitious approval that is, through administrative "silence". It is interesting to note that paragraph 2 of Art. 45 of the LAP Bill as of 2015, which defined the forms of administrative decisions, notes: "administrative decisions made in the oral or tacit form are subjected to the written execution, at the request of the addressee of an administrative decision, within five working days from the day of an appeal. In this case, the requirements applied to the written administrative decision by the current Law are followed". In other words, this article of the framework LAP might be updated with the provision stipulating that after the expiry of a defined period for the adoption of an administrative decision, a permit which has been requested by an individual can be considered to be issued (a fictitious approval) if it is provided by the relevant law (in this case, by the law on permissions and notifications). And the provisions relating to the validity of administrative decision and proceedings for appealing are applied mutatis mutandis. The permit, which is provided through a fictitious approval, should be confirmed in a written form for an applicant.

\subsection{Kyrgyzstan}

The author didn't find the cases of the use of administrative "silence" in the legislation of Kyrgyzstan. Unfortunately, this instrument was not reflected in the LAP provisions of the Kyrgyz Republic as of 2015. Here, the paper focuses on a somewhat contradictory terminological comprehension of an administrative act and the omission of administrative authority. On the one hand, when defining administrative activity, the legislator differentiates the activity of administrative authorities making an external impact and resulting in the adoption of administrative acts and act of commission or omission, which causes legal and/or practical consequences to individuals and legal entities. But paragraph 2 of Art. 4 stipulates that an administrative complaint can be made against the adopted administrative act, which under the procedure of a presentation of this paragraph is divided into an act of commission or omission of administrative authority, that is nothing near so. As legal measures they are independent. Act of commission, as well as omission, has to be distinguished from an administrative act. The wording of Art. 2 of LAP, according to which the effects of sections 1-3, section 15 of LAP cover 
only act of commission of administrative authorities in public relations, is not entirely appropriate. It means a more comprehensive approach.

\subsection{Tajikistan}

"Tacit approval" as the principle of the licensing system in business is fixed in the legislation of the Republic of Tajikistan ${ }^{20}$. The legislator interprets "tacit approval" as a procedure due to which an authorization document is considered to be issued (re-issued, renewed) if the administrative body hasn't decided on application notifying an applicant within the time limit and under the terms prescribed by the above law. Upon the expiry of indicated period for the issuance of authorization document and with a lack of written notification on the part of authorization authority, an applicant can commence an activity for which he has requested authorization document.

The procedure of tacit approval is not applied only to individual types of authorization documents issued by licensing authorities, e.g. in case of a request to grant Dehqan farm (farm enterprise) a certificate on a land leasehold or radio frequency authorization, either a permit for blasting operations, or a permit for users' connection with energy lines, and in other substantiates situations where a public interest strongly prevails.

In case of any situation (tacit approval), a licensing authority draws up a permit for the period for no more than 5 days after expiry of the time limit specified by the law, i. e. ten working days after registration of a request for obtaining an authorization document and appended documents.

It is somewhat difficult to explain the provision under which the legislator of Tajikistan intentionally stipulates: a negative acknowledgment of licensing agency is not considered equivalent to the tacit approval. As well as in other countries of the region, administrative "silence", unfortunately, has not become a subject of the regulation of the Code on Administrative Procedures of the Republic of Tajikistan ${ }^{21}$.

\subsection{Uzbekistan}

For the first time, the principle "tacit approval" was fixed in the special branches of administrative regulation of Uzbekistan (tax, municipal). In particular, it was applied in 2011 in the Resolution of the Cabinet of Ministers of the Republic of Uzbekistan "On additional measures to further improve the use of cash registers with fiscal memory” dated 17 November 2011 № $306^{22}$. As it is known, legal entities and individual

${ }^{20}$ Art. 11 of the Law of the Republic of Tajikistan "On Licensing System".

See: Parliament of the Republic of Tajikistan (2011). Law of the Republic of Tajikistan "On Licensing System" dated August 2, 2011. Akhbori Majlisi Oli of the Republic of Tajikistan, no. 6, art. 606 [О разрешительной системе : Закон Республики Таджикистан от 2 августа 2011 г. Ахбори Маджслиси Оли Республики Таджикистан. 2011. № 6. Ст. 606].

${ }^{21}$ National Center for Legislation under the President of the Republic of Tajikistan. URL: http://mmk.tj/ru/legistation/legislation-base/codecs/ [Национальный центр законодательства при Президенте Республики Таджикистан. URL: http://mmk.tj/ru/legistation/legislation-base/ codecs/].

Akhbori Majlisi Oli of the Republic of Tajikistan, 2007, no. 2, art. 101 [Ахбори Маджлиси Оли Республики Таджикистан. 2007. № 2. Ст. 101].

Akhbori Majlisi Oli of the Republic of Tajikistan, 2007, no. 2, art. 74 [Ахбори Маджлиси Оли Республики Таджикистан. 2007. № 2. Ст. 74].

22 "Procedure for registering a cash register machine with fiscal memory in the state tax service at the place of business with the issuance of a registration card for a cash register machine with 
entrepreneurs shall perform monetary transactions using cash registers (CR) with fiscal memory when selling goods, performing work, providing the population with services. Before the commencement of activities, an entrepreneur shall register CR in a tax authority and obtain a document of permitting nature - registration card. The entrepreneur receives it upon his application and acquires the right to sell goods (works, services) for cash payment for the population. Paragraph 13 of the mentioned governmental order consolidated a provision which states that if a tax authority doesn't notify an entrepreneur on a refusal of the provision of a registration card and doesn't provide it within a fixed timeframe (five working days), the entrepreneur has the right to sell goods (works, services) for cash payment with the population using CR but, at the same time, by notifying a tax authority in a written form. This is the only case of the use of administrative "silence" in tax relations, but it may be disseminated in other situations of the interaction of a taxpayer and tax authority. For example, according to Art. 49 of the Tax Code of the Republic of Uzbekistan, regulating the accounting of taxpaying and other obligatory payments, a taxpayer is entitled to demand drawing up an act of reconciliation of fulfillment of tax obligation on payment of taxes and other mandatory charges from state revenue authority. However, this provision has two gaps: first, there is no note about the term when tax authority shall sign an act of fulfilment of tax obligation; second, the issue of consequences of the omission of the tax authority is not resolved. Omission (silence) of tax authority also shall be considered as illegal as well as rejection note. Then, it is important to apply the rule of administrative silence in this article, in particular, to set a standard according to which omission (silence) of tax authority during five working days since the provision of tax authority with an act of reconciliation means its positive response ("tacit" decision that is a decision confirming the signing of reconciliation act by an authorized person).

Another situation that is not regulated by the legislation but subjected to the application of administrative "silence" in tax relations is the use of property tax exemptions by individuals. In accordance with Art. 275 of the Tax Code of the Republic of Uzbekistan, individuals can use most tax exemptions for the payment of this tax after an unassisted presentation of a document specified for a particular legal status. For example, women who have ten and more children afford the certificate for the confirmation of parental status to tax authority, which was issued by the self-government body; pensioners a pensioner ID card; disabled persons of groups I and II - a medical note of disability evaluation board etc. Thus, state revenue authorities conduct the assessment of property tax for individuals relying on the data from relevant documents as well as on the data of an authority implementing an official registration of real estate title. However, upon

fiscal memory" (Appendix 1 to the Regulation on the procedure for the use of cash registers with fiscal memory when making cash settlements with the population). See: Cabinet of Ministers of the Republic of Uzbekistan (2011). Resolution of the Cabinet of Ministers of the Republic of Uzbekistan "On additional measures to further improve the use of cash registers with fiscal memory" dated November 17, 2011 № 306. Legislation Bulletin of the Republic of Uzbekistan, no. 47, art. 488 [О дополнительных мерах по дальнейшему совершенствованию применения контрольно-кассовых машин с фискальной памятью : Постановление Кабинета Министров Республики Узбекистан от 17 ноября 2011 г. № 306. Собрание законодательства Республики Узбекистан. 2011. № 47. Ст. 488]. 
delivery of exemption entitlement, a tax authority doesn't take any actions (a procedural decision). But to exclude mistakes in the final assessment of tax payment and to respect the right of an individual to relevant tax exemption in case of loss of submitted document by a tax authority, it is expedient to specify the duties of an appointed official and to establish a rule: if within five working days since the provision of a tax authority with a document on entitlement on tax exemption the tax authority hasn't notify an individual of the fact of document reception and its recording (administrative "silence") through procedural act, it is supposed that assessment of property tax was conducted taking into account the right of the taxpayer to property tax privilege.

In 2014, Uzbekistan's government took the first shot to introduce the scheme "administrative silence" on the system level, however that referred to the individual issue - the application of the responsibility to an entrepreneur. Thus, it was proposed to establish the order whereby liability for the conduct of activities without a permit is not applied when an authorized agency didn't issue a document or didn't refuse its issuance during the period established by law for considering the application on the provision of business entities with a permit ${ }^{23}$. Despite some restrictive elements of this idea, it can be a basis for a gradual implementation of "administrative silence".

Previously, in 2012, the Law of the Republic of Uzbekistan "On Authorization Procedures in Entrepreneurial Activity" dated 20 December 2012 introduced a provision, which is equivalent to provisions of laws of Kazakhstan and Tajikistan regulating the licensing practice. Thus, part 3 of Art. 18 consolidated the provision that if an authorized body within a period of processing of the application on authorization document doesn't award a permit to a business entity or doesn't deny its issuance, then upon the expiry of the established period, the business entity is entitled to do an act and/ or to undertake a particular activity for the implementation of which he has intended to take out a document of permissive nature. Besides, he shall notify an authorized body in a written form, except for cases when the time limits for the examination of business entity's application on the issuance of a permit by authorized body exceed 30 working days and other cases specified in the provisions on the order of licensing procedures ${ }^{24}$.

In such cases, an authorized body, within five working days upon the receipt of written notification of business entity, shall award authorization document to him. Prior the receipt

\footnotetext{
${ }^{23}$ Paragraph 2, section I "Programs of additional measures to improve the investment climate and business environment, efficiency raising for the promotion of development of entrepreneurial activity for 2014-2015” (annex № 1). See: President of the Republic of Uzbekistan (2014). Presidential Decree of the Republic of Uzbekistan "On additional measures to further improve the investment climate and business environment in the Republic of Uzbekistan" dated April 7, 2014 № УП-4609. Legislation Bulletin of the Republic of Uzbekistan, no. 15, art. 163 [О дополнительных мерах по дальнейшему совершенствованию инвестиционного климата и деловой среды в Республике Узбекистан : Указ Президента Республики Узбекистан от 7 апреля 2014 г. № УП-4609. Собрание законодательства Республики Узбекистан. 2014. № 15. Ст. 163]

${ }^{24}$ Parliament of the Republic of Uzbekistan (2012). Law of the Republic of Uzbekistan "On licensing procedures in business activity" dated December 20, 2012. Legislation Bulletin of the Republic of Uzbekistan, no. 51, art. 575 [О разрешительных процедурах в сфере предпринимательской деятельности : Закон Республики Узбекистан от 20 декабря 2012 г. Собрание законодательства Республики Узбекистан. 2012. № 51. Ст. 575].
} 
of document of authorization nature, the record of provided documents with a mark of date of their receipt and written notification, which are sent by the business entity to the authorized body, are equated with a document of authorization nature and basis for the conduct of an act and/or performance of such activity. An individual can't be brought to liability for the performance of activities without a document of authorization nature (the last proposal was introduced in the statutory wording dated August 20, 2015).

The legislator of Uzbekistan postulated not only a guarantee of the enjoyment of the right to petition but also, that is important to highlight, the guarantee of examination of appeal through marking measures on full, unbiased and well-timed actions of officials towards the safeguards for the rights and interests of the applicant (see Arts. 12 and 13 of the Law of the Republic of Uzbekistan "On appeal of individuals and legal entities"25). The duty of a government body considered the individual's application includes not only immediate and written notification on the results of consideration but also a duty to control complying with the decision. This creates a basis for large-scale implementation of the instrument of administrative "silence", including in the LAP draft of the Republic of Uzbekistan.

\section{Conclusions}

Administrative "silence" is applied in the legislation of countries of Central Asia (legislation on authorization procedures in business area, tax legislation) without being named directly. The legislator can use it as a fictitious administrative act (fictitious favourable decision or tacit consent). In the legislation and law enforcement practice, there are no cases when administrative "silence" would use as a fictitious negative decision of an administrative body (implicit denial) ${ }^{26}$. In all cases, a clause on the classification of administrative silence as a fictitious act of positive character should be fixed in the framework law on administrative procedures.

Administrative "silence" is a type of the administrative act, but in view of the legislative clause, gaining a status (equivalent) of a positive decision. In other words, administrative "silence" allows an applicant to commence his activities or to consider the matter to be solved if the permit would be issued. Responsibility for the consequences of such activity falls on the administrative body.

Application of the principle of administrative "silence" has impartial limits: first, it is essential to take into account the features of administrative regulation excluding some practices, e. g. licensing of individual types of activity where "silence" will not become an effective way for the accomplishment of the administrative procedure because of complicated nature of the administrative case and where the application of tacit consent can cause serious consequences for public interests; second, the use of "silence gives consent" of the administrative authority is expedient in the legal relations where

${ }^{25}$ Parliament of the Republic of Uzbekistan (2014). Law of the Republic of Uzbekistan "On appeal of individuals and legal entities" dated December 3, 2014. URL: https://lex.uz/ $\operatorname{docs} / 2509998$ [Об обращениях физических и юридических лиц : Закон Республики Узбекистан от 3 декабря 2014 г. URL: https://lex.uz/docs/2509998].

${ }^{26}$ Vedel, G. (1973). Administrative law of France. Moscow: Progress, pp. 144 [Ведель Ж. Административное право Франции / пер. с франц. Л.М. Энтина. Москва : Прогресс, 1973. 512 c.]. 
there is a very low degree of official discretion; third, it is necessary to bear in mind that in particular cases, administrative "silence" doesn't allow accommodating the interests of third parties sufficiently that have to be mindful while accomplishing the administrative procedure.

It is worthwhile to classify the types of omission not only for the effectiveness of its challenging, assessment of liability of an official but also the position of the term in the system of such definitions as "a fictitious act" (administrative "silence"), "delay in the adoption of administrative act" ${ }^{\prime 27}$. For example, along with: a) omission, as characteristics of activities of the authority (an official) without initiating of administrative proceedings (none proceeding is perfect, and the very administrative procedure hasn't completed adequately), it takes place b) omission within the framework of initiated administrative proceedings but without the adoption of the relevant administrative act (i. e. however, it is possible that individual actions were conducted and procedural decisions were adopted, the very procedure wasn't completed adequately). These two types of omission are certainly qualified as an illegal activity of administrative authority. But, there is the third type of omission which is interpreted as a grounded decision of administrative authority approved by the legislator. For example, this refers to the case when administrative authority has taken a motivated decision about the dismissal of an application without prejudice if the claim of that sort of application is beyond the scope of LAP. In this context, administrative procedure on such applications is not initiated. For example, the legislator of Kyrgyzstan considers such omission of the administrative authority or an official as legal one (in the context of this situation, a motivated decision is not an administrative act) within a framework of appealing.

In any other case, public authority must make more significant efforts for preventing gaps and improving organization of administrative practice. Omission is a symbol of incompetence, disrespect to individual's dignity and violation of the constitutional principle of accountability and responsibility of state authorities and officials to the society and citizens. From this standpoint, the legislator and executive authority have one more legal opportunity to ensure the rights and interests of applicants, including by using an instrument of administrative "silence" (a fictitious act).

\footnotetext{
${ }^{27}$ See, for example, a conceptual assignment of Art. 43 of LAP of the Republic of Kazakhstan "Extension of term for administrative procedure".
} 


\title{
ФІКТИВНИЙ АДМІНІСТРАТИВНИЙ АКТ: ПЕРСПЕКТИВИ РЕГУЛЯЦЇ̈ У КРАЇНАХ ЦЕНТРАЛЬНОЇ АЗЇ̈
}

\author{
Леонід Хван, \\ кандидат юридичних наук, доцент \\ (Ташкент, Узбекистан)
}

Країни Центральної Азї - Казахстан (двічі: у 2000 р., у 2015-2016 рр.), Киргизстан (двічі: у 2004 р., у 2015 р.), Таджикистан (у 2007 р.) та Узбекистан (двічі: у 2007 р., y 2015-2016 рр.) - намагаються адаптувати в національну правову систему закони про адміністративні процедури. Закони про адміністративні процедури - ие інструмент західного світогляду, інститут європейського адміністративного права, частина європейського розуміння відкритого уряду й ефективного державного регулювання, підходи до якого наведені країни регіону почали розробляти відносно недавно. Замість формального калькування законів про адміністративні прочедури більш важллво знайти відповіді про готовність країни прийняти такі закони в існуючих сочіальних, політичних та економічних реаліях, у тому числі згідно з особливостями національного правопорядку. Зазначається наукова нерозробленість двох ключових положень законів про адміністративні процедури - принципів адміністративних процедур та адміністративного акта. Аналізується можливість імплементації одного 3 варіантів адміністративного акта, прийнятого в результаті фіктивного схвалення (Genehmigungsfiktion). Сьогодні в Центральній Азї̈ діє ї̈ усічена модель - принцип «мовчання - знак згоди» у сфері дозвільних процедур підприємниитва: «якщзо державний орган не представить у встановлені строки мотивовану відмову або дозвільний документ, такий документ вважається виданим (тобто процедура вважається завершеною)». Проводиться порівняльно-правовий аналіз ї̈ застосування у країнах Центральної Азії.

Зроблено низку висновків:

- адміністративне «мовчання» може бути використане законодавцем як фіктивний адміністративний акт (мовчазна згода);

- адміністративне «мовчання» є різновидом адміністративного акта, проте лише за умови законодавчого застереження;

- вказані об 'єктивні обмеження застосування адміністративного «мовчання»;

- класифіковано види бездіяльності для иіілей ефективності його оскарження, з'ясування місия терміна в системі таких дефінічій, як адміністративне «мовчання», «затримка в ухваленні адміністративного акта».

Ключові слова: адміністративні процедури, адміністративний акт, адміністративне «мовчання», фіктивне схвалення, Центральна Азія. 